\title{
Radiocarbon
}

\author{
1970
}

\section{CARBON-ISOTOPE FRACTIONATION DURING \\ DRY COMBUSTION OF OXALIC ACID}

\author{
J. A. LOWDON
}

Geological Survey of Canada, Ottawa, Canada

Grey et al. (1969) have discussed the problems that arise when using the wet oxidation method for the preparation of $\mathrm{CO}_{2}$ from oxalic acid and suggest that, although offering an effective substitute, the dry combustion method also has problems.

Results obtained in this laboratory over the past 9 years indicate that only minor problems arise when using the dry combustion method.

Between January, 1961 and September, 1969, 47 oxalic acid standard $\mathrm{CO}_{2}$ gas samples were prepared. Until January, $1968, \mathrm{C}^{13} / \mathrm{C}^{12}$ determinations were not available to the laboratory. However, anticipating that carbon isotope ratios would become available in the future, some $\mathrm{CO}_{2}$ from randomly selected oxalic acid preparations was kept for future analysis. Thirteen such samples have been analyzed (by Isotopes Inc., New Jersey) dating from 1961 to January, 1969. The results are shown in Table 1.

TABLE 1

$\delta \mathrm{C}^{13}$ values for $\mathrm{CO}_{2}$ from oxalic acid standards prepared by the dry combustion method

\begin{tabular}{lcc}
\hline $\begin{array}{c}\text { Date of } \\
\text { preparation }\end{array}$ & $\begin{array}{c}\mathrm{CO}_{2} \text { yield }(\%) \\
\text { (approx.) }\end{array}$ & $\begin{array}{c}\mathrm{C}^{13}(\%) * \\
(\text { Relative to } \\
\text { PDB standard) }\end{array}$ \\
\hline January, 1961 & 97 & -19.4 \\
July, 1962 & 96 & -17.8 \\
September, 1963 & 100 & -18.4 \\
January, 1964 & 100 & -19.5 \\
September, 1964 & 98 & -18.3 \\
January, 1965 & 100 & -17.8 \\
December, 1965 & 93 & -18.2 \\
August, 1966 & 96 & -17.8 \\
October, 1967-Analysis 1 & 97 & -20.1 \\
1967-1968** Analysis 2 & 97 & -20.2 \\
November, 1968 & 96 & -18.2 \\
January, 1969 & 93 & -20.6 \\
\hline
\end{tabular}

* Analytical error for each determination is $\pm 0.2 \%$.

** The $\mathrm{CO}_{2}$ gas on which this determination was carried out was made up of a mixture of 4 individual oxalic acids, prepared between August, 1967 and April, 1968. 
It has been determined quantitatively, for the volume of the preparation line used in this laboratory, that the expected yield of $\mathrm{CO}_{2}$ for an oxalic acid combustion is ca. $1.5 \mathrm{cms}$ of $\mathrm{CO}_{2}$ gas pressure $/ \mathrm{gm}$ of dry oxalic acid in an expansion volume of $18.5 \mathrm{~L}$. The approximate yields of $\mathrm{CO}_{2}$ given in Table 1 were calculated on this basis.

The only result obtained that shows any appreciable amount of fractionation is the preparation of January, $1969(60 \%$ yield). This reaction was stopped intentionally about halfway through completion in order to verify that incomplete combustion results in fractionation of carbon isotopes (Craig, 1961). With respect to the total of $47 \mathrm{CO}_{2}$ preparations from oxalic acid, only 4 had yields of less than $90 \%$. Because of the "isotope-yield" correspondence, as is evident in Table 1, 2 of these preparations prepared after January 1969 were discarded and not used for counting purposes. It is now our policy to discard all preparations which do not give greater than $90 \%$ of the expected yield. Results show safety in assuming that only slight, or negligible, fractionation occurs if more than $90 \%$ of the oxalic acid is converted to $\mathrm{CO}_{2}$. This should not deter workers from obtaining $\delta \mathrm{C}^{13}$ values as a routine policy, but should lend a little more confidence to the dry combustion method of producing $\mathrm{CO}_{2}$ gas from oxalic acid.

Ignoring the final result (January, 1969) listed in Table 1, the average $\delta \mathrm{C}^{13}$ value is $-18.9 \%$, referred to the $\mathrm{PDB}$ standard, which agrees with the value of $-19.0 \%$ determined by Craig (1961).

It was stated earlier that problems encountered in the preparation of $\mathrm{CO}_{2}$ from oxalic acid by the dry combustion method used in this laboratory appear to be minor. Apart from the fact that the oxalic acid is given no pretreatment prior to combustion, only one change in the normal procedure for the preparation of other organic samples must be made. The normal procedure is fully described in Lowdon et al. (1969) and Lowdon and Blake (1970). For the successful preparation of $\mathrm{CO}_{2}$ from oxalic acid, the temperature of the combustion furnace must be lowered from $700^{\circ} \mathrm{C}$ (for other organic samples) to $450^{\circ} \mathrm{C}$, thus allowing the reaction to proceed very slowly. The reason for this change is not so much that a rapid reaction may enhance the chances of fractionation, but rather that a higher temperature causes rapid evaporation of the oxalic acid, giving rise to explosive mixtures in the combustion tube.

The results discussed here, and our experience have shown that the dry combustion method of preparing $\mathrm{CO}_{2}$ from oxalic acid is reliable and gives reproducible results, provided time and care is taken to convert more than $90 \%$ of the carbon to $\mathrm{CO}_{2}$. The major annoyance in the method is the length of time (ca. $4 \mathrm{hrs}$ for $30 \mathrm{gms}$ of oxalic acid) involved in sample preparation.

\section{ACKNOWLFDGMENTS}

The author wishes to thank W. Dyck, who was in charge of the laboratory from 1959 to 1964, for helpful suggestions for this paper. 
Thanks are also extended to numerous laboratory personnel who assisted in the preparation and measurement of the samples.

\section{REFERENCES}

Craig, Harmon, 1961, Mass-spectrometer analyses of radiocarbon standards: Radiocarbon, v. 3, p. 1-3.

Grey, D. C., Damon, P. E., Haynes, C. V., and Long, Austin, 1969, Carbon-isotope fractionation during wet oxidation of oxalic acid: Radiocarbon, v. 11, p. 1-2.

Lowdon, J. A. and Blake, W., Jr., 1970, Geological Survey of Canada radiocarbon dates IX: Radiocarbon, v. 12, p. 46-86.

Lowdon, J. A., Wilmeth, R., and Blake, W., Jr., 1969, Geological Survey of Canada radiocarbon dates VIII: Radiocarbon, v. 11, p. 22-42. 